\title{
X, Y ve Z Kuşaklarının Eğitim, Öğretmen, Öğrenci Algıları
}

\author{
DOI: $10.26466 /$ opus.948789
}

\author{
Canan Tunç Şahin* - Selçuk Turan** ${ }^{*}$ Oguuzhan Karadeniz ${ }^{* *}$ \\ * Dr. Öğr. Üyesi, Zonguldak Bülent Ecevit Üniversitesi,Ereğli Eğitim Fakültesi, Zonguldak/Türkiye \\ ORCID: $\quad 0000-0003-0997-2124$ \\ ** Dr. Öğr.Üyesi, Zonguldak Bülent Ecevit Üniversitesi, Ereğli Eğitim Fakültesi, Zonguldak/Türkiye \\ E-Posta: selcukturan25@gmail.com ORCID: 0000-0003-2234-6494 \\ *** Doç. Dr., Zonguldak Bülent Ecevit Üniversitesi, Ereğli Eğitim Fakültesi, Zonguldak/Türkiye \\ E-Posta: oguzhankaradeniz25@hotmail.com ORCID: 0000-0002-1717-861X \\ Öz
}

$B u$ araştırmanın amacl; $X, Y$ ve $Z$ kuşağında yer alan bireylerin eğitim, öğretmen ve öğrenciye yönelik algiların belirlemektir. $\mathrm{Bu}$ çalışmada nitel araştırma yöntemlerinden olan olgubilim (fenomenoloji) deseni kullanılmıştır. Araştırmanın katılımcıları amaçlı örnekleme yöntemi ile belirlenmiştir. Araştırmanın çalışma grubunu oluşturan X kuşağından 4, Y kuşağından 5, Z kuşağından 5 olmak üzere toplam 14 kişi ile yart-yapılandırılmış görüşme formu kullanılarak veriler toplanmıştır. Uzman görüşü alınarak hazırlanan görüşme formunda "Ĕ̆itim nedir?", "Bir öğrenciyi tarif eder misin?", "Sence öğrenci nasıl olmalıdır?" ve "Bir öğretmen nasıl olmalıdır?" soruları yer almıştır. Veriler, içerik analizi tekniğiyle işlenmiştir. Araştırma sonucunda X, Y, Z kuşă̆ında yer alan katılımcıların eğitim, öğretmen ve öğrenciye yönelik algıları belirlenmiştir. Katılımcıların eğitim algıları incelendiğinde; X kuşă̆ı eğitimi, tecrübe ve deneyim olarak tanımlarken, Y kuşă̆ının aile, okul ve arkadaş çevresinde öğrenilenler olarak, $\mathrm{Z}$ kuşă̆ının ise toplumdaki davranışlarımız olarak tanımladığı tespit edilmiştir. Kuşakların öğretmen algıları incelendiğinde X kuşağı öğretmeni disiplinli ve sorumlu, Y kuşă̆ı güvenilir ve sabırl, Z kuşağı ise güvenilir, sabırlı ve sevecen olarak tarif etmiştir. Katılımcıların öğrenci algılarn incelendiğ̈inde X kuşă̆̆ öğrenciyi çalışkan ve sorumlu olarak ifade erken, Y kuşă̆ı öğrencinin istekli, terbiyeli, çalışkan ve duygulu olması gerektiğini, Z kuşă̆ı ise ögrencinin saygll ve disiplinli olması gerektiğini ifade etmiştir.

Anahtar Kelimeler: Ĕğitim, Öğretmen, Öğrenci, Kuşak Farklılıkları. 


\title{
Education, Teacher and Student Perceptions of Generations $X, Y$ and $Z$
}

\begin{abstract}
The aim of this study is to determine the perceptions of individuals in the $X, Y$ and $Z$ generations towards education, teachers and students. In this study, the phenomenology design, which is one of the qualitative research methods, was used. The participants of the research were determined by purposive sampling method. Data were collected by using a semi-structured interview form with a total of 14 people, 4 from the $X$ generation, 5 from the $Y$ generation, and 5 from the $Z$ generation, which constitute the study group of the research. "What is education?", "Can you describe a student?", "How do you think a student should be?" and "How should a teacher be?" questions have been included. The data were processed with content analysis technique. As a result of the research, the perceptions of the participants in the $X, Y$ and $Z$ generations towards education, teachers and students were determined. When the participants' perceptions of education were examined, it was found that while Generation $X$ defined education as experience and practice, generation $Y$ defined it as learned around family, school and friends, and generation $\mathrm{Z}$ defined education as our behaviors in society. When the teachers' perceptions of the generations were examined, the generation $X$ described the teacher as disciplined and responsible, the Y Generation as reliable and patient, and the $\mathrm{Z}$ generation as reliable, patient and loving. When the students' perceptions of the participants were examined, Generation X stated that the student should be diligent and responsible early, Generation $Y$ stated that the student should be willing, decent, hardworking and emotional, while Generation Z stated that the student should be respectful and disciplined.
\end{abstract}

Keywords: Education, Teacher, Student, Generation Differences. 


\section{Giriş}

Toplumsal yaşamdaki hızlı gelişmeler ve dönüşümler nesiller arası farklılıklara neden olmuştur. Çağlar değiştikçe nesillerin ihtiyaç ve beklentileri de değişime uğramıştır. Bu toplumsallaşmanın bir sonucudur ve kuşak kavramıla ilişkilidir. Farklı dönemlerde farklı koşullar içinde yetişen kuşaklar birbirlerinden farklı değerlere ve görüşlere sahip olabilirler. Dolayısıyla farklı kuşağa mensup bireylerin bazı konulara veya kavramlara yönelik farklı algılara sahip olması da olağan bir durumdur. Bu durum her kuşağın kendi çağının özellikleriyle yetişmiş olmasından kaynaklanabileceği düşünülmektedir. Bu noktada farklı kuşakların yaşamda karşılaştığ 1 olgu ya da olaylara karşı düşüncelerinin bilinmesi onların daha iyi anlaşılması noktasında önemli görülmektedir.

Kuşak, belli zaman aralığında doğan aynı dönemlerde yaşayan, ortak özelliklere sahip bireylerin oluşturduğu gruplar olarak tanımlanır (Karaaslan, 2014). Zaman, insanların hayata bakış açılarını, beklenti ve önceliklerini, tutum ve davranışlarını değiştirebilir (Adıgüzel, Batur ve Ekşili, 2014). Toplumsallaşma süreçleri, siyasi, sosyolojik, ekonomik olaylardan ve gelişmelerden aynı anda etkilenen kuşaklardaki bireylerin inanç, tutum, değer ve davranışlarında benzerlikler görülür (Tezcan, 2017). Farklı dönemlerde ve farklı kültürel değerlerle sosyalleşmiş olan bireyler gerek duygusal ve düşünsel gerekse de normatif değerlerde ayrışmakta ve farklılaşmaktadırlar (Duman, 2019). Bu ayrışma, eğitim açısından bakıldığında yetişkinlerle genç kuşaklar arasında görülmektedir. Bu farklılaşmanın daha net anlaşılması için öncelikle kuşakların özelliklerinin incelenmesi gerekir.

Kuşaklar; kurucular kuşağı, bebek patlaması kuşağı (baby boomers), X kuşağı, Y kuşağı, Z kuşağı ve $\alpha$ (alfa) kuşağı olarak sınıflandırılır (Berkup, 2014; Bütün ve Güneş, 2020; Sarı ve Harta, 2018; Taş, Demirdöğmez ve Küçükoğlu, 2017; Yüksekbilgili, 2013). Kuşak kavramı yaklaşık olarak 20-25 yıllık yaş kümelerini oluşturan, aynı zaman diliminde doğan bireylerden oluşur. Doğdukları zamandaki toplumsal olaylardan ve gelişimlerden aynı anda etkilenmişlerdir. Ancak günümüzdeki nesiller oldukça hızlı değişmeye başlamıştır ki bu sınıflama geçerliliğini yitirmiştir (Bütün ve Güneş, 2020). Bu kuşaklar içinden 
araştırma konusu çerçevesi içinde $\mathrm{X}, \mathrm{Y}, \mathrm{Z}$ kuşakların genel özellikleri incelenmiştir.

X kuşağı, 1965 ve 1979 yılları arasında doğanları kapsayan kuşaktaki bireylerden oluşur. Ülke nüfusunun \%20'den fazlasını oluşturur (Türkiye İstatistik Kurumu, 2018). Bu kuşaktaki bireylerin çoğu iş hayatındadır. Bu nesil teknolojik sistemlerin dönüşümüyle özellikle bilgisayarlarla iş yapma şekline adapte olmaya çalışan bir nesil olmuştur. Bu kuşağa ait bireylerin yönetici olmaya başlamasıyla teknolojik sistemlerin daha fazla kullanıldığı görülmüştür (Yelkikalan ve Altın, 2010). Y kuşağı, 1980 ile 2000 yılları arasında doğanlardır. Ülke nüfusunun \%35'inden fazlasını oluşturur (TUIK, 2018). Bu kuşak için Milenyum Kuşağı (Pedró, 2006), Oyun Kuşağ1 (Oblinger ve Oblinger, 2005), Dijital Kuşak, Dijital Yerliler (Prensky, 2001) gibi isimler kullanılır. Söz konusu kuşak dijital teknolojinin yoğun olarak kullanıldığı bir dönemde doğmuştur. Küresel ekonomi ve kültürler arası etkileşimin arttığ 1 bir dönemde yaşayan bu kuşağın sosyal medyayı etkin bir şekilde kullandığı görülmektedir (Bütün ve Güneş, 2020). Bu kuşaktakiler, görsel yetenekleri gelişmiş, özgürlüğü ve esnekliği seven, takım çalışmasına yatkın, yeni yaklaşımlara açık bireylerdir (Lower, 2008). Z kuşağı, 2000-2010 yılları arasında doğanları kapsamaktadır. İnternet kuşağı ya da kristal kuşak olarak isimlendirilir (Demirkaya, Akdemir, Karaman ve Atan, 2015). İleri teknoloji içinde yetişen bireyler bilgisayarı kitaba, metinleri ise konuşmaya tercih etmektedirler (Sarı ve Harta, 2018). Dışarıda çok zaman geçirmeyen $\mathrm{Z}$ kuşağı yalnız yaşamayı ve bireyselleşmeyi tercih etmektedirler (Bütün ve Güneş, 2020).

Kuşaklar arası farklılıklardan kaynaklanan özellikler bireylerin olay, olgu ve kavramlara bakışlarını da etkilemektedir. Toplumda yaşanan değişim ve dönüşümlere paralel olarak toplumda yaşayan farklı kuşaklardaki bireylerin eğitime yönelik algıları da değişmektedir (Özoğlu, Gür ve Altınoğlu, 2013). Alanyazın incelendiğinde Türkiye'de kuşaklararası eğitim algılarının incelendiği çalışma az sayıdadır (Nayır ve Çınkır, 2017). Yapılan çalışmalar genelde kuşaklararası değer farklılıkları (Aygün ve İmamoğlu, 2002; Bowman, 2010; Morsümbül, 2014; Kaya, 2013), kuşaklararası çatışma (Arslan ve Polat, 2016) ve kuşakların iş hayatındaki yeri (Adıgüzel, Batur ve Ekşili, 2014) konularına yoğunlaşmaktadır. $\mathrm{Bu}$ araştırmalar incelendiğinde kuşaklararası değer 
farklılıklarının eğitime yansıdığı ve bu doğrultuda öğretmen ve öğrencilere yüklenen anlamında değiştiği söylenebilir (Aygün ve İmamoğlu, 2002; Bowman, 2010; Kaya, 2013; Morsümbül, 2014).

Öğretmenlik bireylerin yaşantısı üzerinde dönüştürücü gücü olan bir meslektir. Bu mesleğin doğasında öğretimsel etkinlerin yanında öğrencilere rol model olma ve onları yaşama hazırlama vardır. Millî Eğitim Bakanlığı (2012) öğretmen niteliklerini profesyonellik, adalet, dürüstlük, doğruluk, mesleki bağlılık, sürekli gelişime açıklık, hizmette sorumluluk, eşitlik, yolsuzluk yapmama, tarafsızlık, saygı, kaynakları etkili kullanabilme, sağlıklı ve güvenli bir ortam sağlayabilmek olarak belirlemiştir.

Öğretmenin bileşeni olduğu eğitim sistemi dönemin ekonomik, siyasi ve toplumsal etkilerine dayanır bu nedenle öğretmenlik mesleğinin ve öğretmenden beklenen niteliklerin dönemin özelliklerinden etkilenerek dönüştüğü görülür (Ünal, 2011). Dönemin siyasi, ekonomik, teknolojik, toplumsal yapısı değiştikçe öğretmen ve öğretmenlik mesleğinin yapısı da değişebilmektedir (Yapıcı ve Yapıcı, 2003, Yıldız, 2013). Teknolojinin hızla gelişmesi öğrenme ortamlarında öğretmen ve öğrenen açısından değişime sebep olmuştur. Genç kuşaklarda yer alan bireylerin teknolojiyi daha rahat kullanabilirken, yaşlı gruplardaki bireylerin teknoloji kullanımında zorluk yaşadığ tespit edilmiştir (Öztürk, 2021). Bu durum toplumsal olgudur ve kuşaklar arası farklılıklar dijital vatandaşlık kavramını gündeme getirmektedir. Buna göre teknolojinin içinde doğan nesil ( $Y$ ve $Z$ kuşağı) "dijital vatandaş", teknolojinin yaygın olmadığ dönemde doğan nesil (X kuşağı) "göçmen" olarak adlandırılır (Prensky, 2001) . Bu farklılık öğrenciler nezdinde bazı öğretmenleri çağın gerisinde olarak düşündürmektedir. Öğretmenlik mesleği kuşak farklılıklarına bağlı olarak dijital vatandaşlık ve göçmenlik arasında dönüşüm geçirmektedir.

Eğitimde yenileşme hareketleriyle birlikte öğrenme öğretme kuramlarında yapılan değişikler öğretmene ve öğrenciye yüklenen rollerde dönüşüme sebep olmuştur (Kayaalp ve Şimşek, 2021). Yapılandırmacı yaklaşımın eğitimde yaygın olarak benimsenmesiyle öğretmene ve öğrenciye biçilen roller de değişmiştir. Artık öğretmen merkezde olan değil, rehber ve yol göstericidir (Yuen ve Hau, 2006). Öğretmenin görevi bilgi otoritesi olmak yerine öğrencinin bilgiye sahip olması için rehber olmaktır (Tezcek, 2013, s.124). Bu öğrenme ve öğretme yaklaşımında 
öğretmene biçilen pasif rol öğretmene ve öğretmenlik mesleğinin etkisiz olduğuna dair bir alg1 oluşturmaktadır (Ünal, 2011; Yıldız ve Ünlü, 2014). Öğretmenlik geçmiş dönemde bilgi otoritesi olarak görülürken günümüzde "bakıcı" olarak görülmektir. Bu söylemler öğretmenlik mesleğini değersizleştirmektedir (Fwu ve Wang, 2010; Hall ve Langton, 2006, Ünsal ve Bağçeci, 2016). Alanyazındaki araştırmalar incelendiğinde öğretmenlerin toplum nezdinde mesleklerinin saygınlığını yitirmeye başlaması öğretmenleri üzen bir durumdur (Aydın, Demir ve Erdemli, 2016; Celep, 2004; Gök, 2003; Karaman, Acar, Kılınç, Buluş ve Erdoğan, 2013; Ozankaya, 2002, Özoğlu, Gür ve Altunoğlu, 2013; Özoğlu, 2010; Özpolat, 2002; Semerci, Semerci, Eliüşük ve Kartal, 2012; Ünsal ve Bağçeci, 2016; Ünsal, Ağçam ve Korkmaz, 2017; Ünsal,2018; Yıldız ve Ünlü, 2014).

Eğitim, toplumsal gelişmelere bağlı olarak sürekli değişmekte ve gelişmektedir. Toplumda yaşanan sosyal, ekonomik, politik ve teknolojik gelişmeler eğitimi ve eğitimin bileşenleri olan öğretmen ve öğrencilere yönelik algıları da etkilemektedir. Ekonomik, siyasal, sosyal ve teknolojik gelişmelerin kuşakların yaşam tarzlarını değiştirmesi ve şekillendirmesi göz önünde bulundurulduğunda toplumda yaşayan farklı kuşakların eğitim, öğretmen ve öğrenci algılarının incelenmesi oldukça önemlidir. Bu araştırmanın amacı X, Y, Z kuşaklarında yer alan bireylerin eğitim, öğretmen, öğrenci algılarını belirlemektir. Belirlenen amaca yönelik derinlemesine tespitlerde bulunmak için aşağıdaki alt problemler belirlenmiştir:

1. $X, Y, Z$ kuşaklarının eğitime yönelik algıları nelerdir?

2. $X, Y, Z$ kuşaklarının öğretmene yönelik algıları nelerdir?

3. $X, Y, Z$ kuşaklarının öğrenciye yönelik algıları nelerdir?

Bu çalışmayla eğitim, öğretmen ve öğrenci kavramlarının literatürde $X$ kuşağ (55-40 yaş), Y kuşağı (39-41 yaş) ve Z kuşağı (20 yaş ve altı) olarak tanımlanan farklı üç kuşak üzerinden nasıl algılandı̆̆ı ve yorumlandığ1 ortaya koyulmuştur (Bütün ve Güneş, 2020; Demirkaya vd., 2015; Yelkikalan ve Altın, 2010). 


\section{Yöntem}

Bu bölümde araştırmanın deseni, araştırmaya katılanlara ilişkin bilgiler, veri toplama aracı ile verilerin analizi süreçlerine ilişkin bilgiler verilmiştir

Araştırmanın Deseni: $\mathrm{Bu}$ araştırma $\mathrm{X}, \mathrm{Y}$ ve $\mathrm{Z}$ kuşağında yer alan bireylerin eğitim, öğretmen ve öğrenciye yönelik algılarını belirlenmek amacıyla nitel araştırma yöntemlerinden olgu bilim (fenomolojik) araştırmasıdır. Olgu bilim (fenomenoloji) deseni farkında olduğumuz ancak derinlemesine ve ayrıntılı anlayışa sahip olmadığımız olgulara odaklanmaktadır (Yıldırım ve Şimşek, 2008, s.72). Araştırmacının odaklandığı temel nokta bir olay/olgu/kavram ile ilgili katılımcıların deneyimlerinin ne ifade ettiğidir. Olgu bilim çalışmalarında amaç bir olgu ile ilgili deneyimin ya da gerçeğin tanımlanmasıdır (Creswell, 2008).

Katılımcılar: X, Y ve Z kuşakları hedef alınarak hazırlanan bu çalışmada, doğum yılları odaklı bir çalışma grubu oluşturulmuştur. Araştırmanın amacı doğrultusunda seçilen her bir katılımcının, araştırmaya konu olan bir kuşağa mensup olması beklenmektedir. Araştırma X kuşağından 4, Y kuşağından 5 , Z kuşağından 5 olmak üzere toplam 14 kişi ile yapılmıştır. Araştırmanın katılımcıları amaçlı örnekleme yöntemi ile belirlenmiştir. Katılımcıların belirlenmesinde amaçlı örnekleme yöntemleri arasında yer alan kolay ulaşılabilir örnekleme kullanılmıştır. (Büyüköztürk, Çakmak, Akgün, Karadeniz ve Demirel, 2009). Olgubilim araştırmalarında deneyimlerin daha iyi anlaşılması için fazla katılımcıya ihtiyaç olmadığı üç, beş veya on katılımcıyla çalışmaların gerçekleştirilebileceği iddia edilir (Güler, Halıcıoğlı, Taşgın, 2013). Katılımcılar araştırmaya katılmadan önce araştırma hakkında bilgilendirilmiş ve gönüllü olarak araştırmaya katılmışlardır. Araştırmanın etik izni Zonguldak Bülent Ecevit Üniversitesi Etik Kurulu'ndan (2021/76) alınmıştır. Etik ilkeler gereği katılımcıların isimleri gizli tutulmuş her katılımcıya mensup olduğu kuşağ1 ve yaşını simgeleyen rumuzlar verilmiştir. Katılımcılara ilişkin bilgiler Tablo 1'de verilmiştir. 
Tablo 1. Katılımcılara ilişkin bilgiler

\begin{tabular}{lllll}
\hline Katılımcı Kodları & Cinsiyet & Yaş & Kuşak & Meslek \\
\hline Z7 & Kadın & 7 & Z & Öğrenci (ilkokul) \\
Z10 & Kadın & 10 & Z & Öğrenci (ilkokul) \\
Z15 & Kadın & 15 & $\mathrm{Z}$ & Öğrenci (lise) \\
Z17 & Kadın & 17 & $\mathrm{Z}$ & Öğrenci (lise) \\
Z20 & Kadın & 20 & $\mathrm{Z}$ & Öğrenci (ünv) \\
Y21 & Kadın & 21 & Y & Öğrenci (üniv) \\
Y23 & Kadın & 23 & Y & Siyaset Bilimi Mezunu \\
Y30 & Kadın & 30 & Y & Ev hanımı \\
Y32 & Erkek & 36 & Y & Öğretmen \\
Y36 & Erkek & 36 & Y & Avukat \\
X42 & Kadın & 42 & $X$ & Mühendis \\
X46 & Kadın & 46 & $X$ & Öğretim Üyesi \\
X50 & Erkek & 50 & $X$ & Öğretmen \\
X55 & Erkek & 55 & $X$ & İşçi \\
\hline
\end{tabular}

Veri Toplama Aracı: Araştırma verilerinin toplanmasında görüşme yöntemi uygulanmıştır. Olgu bilim araştırmalarında veriler toplanırken genelde görüşme yöntemi kullanılır, uygulanacak görüşme tekniği ise yapılandırılmamış ya da yarı yapılandırılmış görüşme tekniğidir (Güler, Halıcıŏglı, Taşgın, 2013, s.243). Önceden belirlenmiş bir dizi görüşme prosedürünü temel alarak sürdürüldüğü için daha sistematik ve karşılaştırılabilir bilgi sağlayan yarı yapılandırılmış görüşme tekniği araştırmacıya önemli bir kolaylık sağlar (Yıldırım ve Şimşek, 2008, s.283). Araştırmacı tarafından hazırlanan yarı yapılandırılmış görüşme formundaki soruların iç ve dış geçerliğini sağlamak için, görüşme formu iki uzman tarafından incelenmiştir. Uzmanlardan gelen dönütlerle forma son şekli verilmiştir. Uzmanlardan gelen dönütlerin uyum yüzdesi için Miles ve Huberman (2015) formülünden yararlanılmıştır. Uyum yüzdesi, $\% 85$ olarak bulunmuştur. Bu uyumun \%70'ten yüksek olması gerektiği (Tavşancıl ve Aslan, 2001) için araştırmada yapılan içerik analizi güvenilir kabul edilmiştir. Görüşme protokolünün giriş bölümünde her bir katılımcı araştırmanın amacı hakkında bilgilendirilmiştir. $X, Y$ ve $Z$ kuşağı katılımcılarının eğitim öğretmen ve öğrenci ile ilgili algılarını belirlemek amacıyla "Eğitim nedir?", "Bir öğrenciyi tarif eder misin?", "Sence öğrenci nasıl olmalıdır?" ve "Bir öğretmen nasıl olmalıdır?" soruları sorulmuş, bu sorular görüşmenin gidişatına bağlı olarak çeşitlendirilmiş, kişinin yanıtlarını açması sağlanmaya çalışılmıştır. 
Verilerin Analizi: Araştırmada yarı-yapılandırılmış görüşmeler yoluyla elde edilen nitel veriler içerik analizi tekniğiyle incelenmiştir. İçerik analizi tekniği aşağıdaki aşamalar dikkate alınarak gerçekleştirilmiştir:

Kodların belirlenmesi; görüşmelerden sonra, görüşüne başvurulan her katılımcı için ayrı bir word dosyası açılarak tüm görüşme dökümü bu dosyaya aktarılmıştır. Dosyalara aktarılan tüm bu görüşmeler araştırmacıların her biri tarafından titiz bir şekilde okunarak sistematik kodlama işlemine geçilmiştir. Kodlamada analiz birimi olarak kelime öbekleri ve cümleler kullanılmıştır. Kodlama sürecinde, cümlelerdeki gizli ve açı ifadelerin deşifre edilmesinde hem katılımcıların söyledikleri sözcükler hem de araştırmacı tarafından katılımcıların ifade etmek istediklerini daha iyi temsil edecek kavramlar kullanılmıştır.

Kodlamaların karşılaştırılması ve doğrulanması: Tüm görüşme içeriklerinin kodlanması her bir araştırmacı tarafından bağımsız olarak ayrı ayrı yapıldıktan sonra bunlar karşılaştırılmış, uygun kodlamalar üzerinde görüş birliği oluşana kadar kodlamalar yeniden yapılmıştır.

Temalarn belirlenmesi: Kodlar arasındaki benzerlik ve farklılıklar esas alınarak, kategoriler oluşturulmuş ve kategorilerden temalara gidilmiştir.

Temaların analizi: Temaların analizinde çetele tablosu oluşturularak hangi katılımcı hangi tema, kategori ve alt tema altında görüş bildirdiği tematik olarak verilmiştir. Nitel araştırmalarda bu tür tabloları kullanılarak konu ile ilgili okuyucuya betimsel ve gerçekçi bir resim sunulur (Yıldırım, Şimşek, 2008, s.27). Bu çalışmada verilerin tema analizi sonuçlarının çetele tablosu kullanılarak verilmesi uygun görülmüştür. Örneğin X, Y, Z kuşağı katılımcıların eğitime ilişkin algılarına yönelik tema analizi eğitim ana temasında, eğitimin tanımı, eğitimin anlamı, eğitimin içeriği alt temaları olarak belirlenmiştir. Tematik veri analizi sonrası eğitimin tanımı alt temasına ilişkin katılımcıların görüşlerine ilişkin çetele tablosu örnek olarak Tablo 2' de verilmiştir. 
Tablo 2. X, Y, Z Kuşă̆ı Katılımcıların Eğitime İlişkin Algıları

\begin{tabular}{|c|c|c|c|c|}
\hline Tema & Kodlar & $\begin{array}{l}X(55-40 \text { yaş }) \\
(\mathrm{n}=2)\end{array}$ & $\begin{array}{l}\mathrm{Y}(39-21 \text { yaş }) \\
(\mathrm{n}=4)\end{array}$ & $\begin{array}{l}Z(20 \text { yaş ve } \\
\text { altı) } \\
(n=5)\end{array}$ \\
\hline \multirow{8}{*}{ Eğitimin Tanımı } & Bilgidir. & & $\sqrt{ }$ & $\sqrt{ } \sqrt{ }$ \\
\hline & $\begin{array}{l}\text { Aile, arkadaş, çevreden öğrendi- } \\
\text { klerimizdir. }\end{array}$ & & $\sqrt{ }$ & $\sqrt{ } \sqrt{ }$ \\
\hline & Gelişimdir. & & $\sqrt{ }$ & $\sqrt{ }$ \\
\hline & $\begin{array}{l}\text { Tecrübedir. } \\
\text { İstendik davranış geliştirmedir. }\end{array}$ & $\sqrt{ }$ & $\sqrt{ }$ & $\begin{array}{l}\sqrt{ } \sqrt{ } \\
\sqrt{ }\end{array}$ \\
\hline & Süreçtir. & $\sqrt{ }$ & $\sqrt{ }$ & \\
\hline & Görevdir. & $\sqrt{ }$ & & \\
\hline & Değişimdir. & $\sqrt{ }$ & & \\
\hline & Değerlerdir. & $\sqrt{ } \sqrt{ }$ & & \\
\hline
\end{tabular}

Araştırmanın geçerlilik ve güvenirliliğin sağlanması için inandırıcılık, aktarılabilirlik ve tutarlılık prensipleri belirlenmiştir (Lincoln ve Guba, 1985). Araştırmada inandırıcıllığı sağlamak için katılımcı dürüstlüğünü destekleyen taktiktikler kullanılmıştır. Araştırma, samimi olarak katkı sağlayacak, özgür iradesiyle veri sunmaya hazır kişilerle yürütülmüştür. Katılımcılar açık sözlü olmaları konusunda teşvik edilmiş ve istediklerinde çalışmadan ayrılabilecekleri açıklanmıştır (Shenton, 2004). Araştırmanın inandırıcılığını sağlamak için araştırma analizleri iki kodlayıcı tarafından analiz edilmiştir. Kodlayıcıların veriyi analiz ederken, benzer kodlar kullanıp kullanmadıklarını tespit etmek için üzerinde uzlaşılan kod sayısının toplam uzlaşılan ve uzlaşılamayan kod sayısına bölünmesiyle bulunan kodlayıcılar arası güvenilirlik oranı $\% 90$ olarak tespit edilmiştir. Bu oran veriler arasındaki uyum için yeterli görülür (Miles ve Huberman, 2015). Araştırmanın dış geçerliliğini arttıran unsurlardan biri de aktarabilirliktir. Araştırma boyunca yapılanların araştırma deseni, veri toplama araçları, veri analizi süreci açık ve anlaşılır bir dille yazılmasına özen gösterilmiştir. Ayrıca araştırmada toplanan verilerle uzun süre meşgul olunması, verilerin başka bir araştırmacıya incelettirilmesi ve katılımcıların ifadelerinin araştırmanın tutarlılığını arttıran unsurlardır.

Araştırmanın bazı sınırlılıkları bulunmaktadır. Sınırlılıklardan biri bu araştırmanın sınırlı sayıda katılımcıyla yürütülmesidir. Araştırmanın bir diğer sınırlılığı tekrarlanabilirliği ile alakalıdır. Olgu bilim araştırmalarında her araştırmacının farklı veriler toplaması ve farklı 
yorumlanması söz konusudur. Çalışmanın bulguları ve sonucu katılımcılarla yapılan görüşmelerle sınırlı kalmaktadır.

\section{Bulgular}

X, Y, Z Kuşaklarının Eğitime Yönelik Algıları: Bu başlık altında katılımcıların eğitime ilişkin algılarına yönelik bulgular yer almaktadır. Katılımcıların eğitime ilişkin algıları eğitimin tanımı, eğitimin içeriği ve eğitimin amacı temalarına göre incelenmiştir.

Tablo 3. X, Y, Z Kuşă̆ı Katılımcıların Ĕ̆itime İlişkin Algıları

\begin{tabular}{|c|c|c|c|c|}
\hline Tema & Kodlar & $\begin{array}{l}X(55-40 \text { yaş }) \\
(n=5)\end{array}$ & $\begin{array}{l}Y(39-31 \text { yaş }) \\
(n=5)\end{array}$ & $\begin{array}{l}\mathrm{Z}(20 \text { yaş ve } \\
\text { altı) } \\
(\mathrm{n}=5)\end{array}$ \\
\hline \multirow{9}{*}{ Eğitimin Tanım } & Bilgi & & $\sqrt{ }$ & $\sqrt{ } \sqrt{ }$ \\
\hline & Aile, arkadaş, çevreden öğrenilenler & & $\sqrt{ } \sqrt{ }$ & $\sqrt{ } \sqrt{ }$ \\
\hline & Gelişim & $\sqrt{ }$ & $\sqrt{ }$ & $\sqrt{ }$ \\
\hline & Tecrübe & $\sqrt{ }$ & & $\sqrt{ } \sqrt{ }$ \\
\hline & 1 İstendik davranış geliştirme & & $\sqrt{ }$ & $\sqrt{ }$ \\
\hline & Süreç & $\sqrt{ } \sqrt{ }$ & $\sqrt{ }$ & \\
\hline & Görev & $\sqrt{ }$ & & \\
\hline & Değişim & $\sqrt{ } \sqrt{ }$ & & \\
\hline & Değerler & $\sqrt{ } \sqrt{ } \sqrt{ }$ & & \\
\hline \multirow{8}{*}{ Eğitimin İçeriği } & Aileden öğrenilenler & & & $\sqrt{ } \sqrt{ } \sqrt{ }$ \\
\hline & Dersler, kitaplar & & & $\sqrt{ } \sqrt{ }$ \\
\hline & Okul, kurslar, öğretmen, müdür & & & $\sqrt{ } \sqrt{ } \sqrt{ }$ \\
\hline & Arkadaşlar & & & $\sqrt{ }$ \\
\hline & Yaşam boyu & $\sqrt{ }$ & $\sqrt{ } \sqrt{ }$ & $\sqrt{ } \sqrt{ }$ \\
\hline & Toplumda nasıl davranılması gerektiği & & & $\sqrt{ }$ \\
\hline & Düşünceler/görüşler & $\sqrt{ }$ & $\sqrt{ }$ & \\
\hline & Deneyimler/tecrübeler & $\sqrt{ } \sqrt{ }$ & $\sqrt{ } \sqrt{ }$ & $\sqrt{ }$ \\
\hline \multirow{7}{*}{ Eğitimin Amacı } & Yeni bilgiler öğrenmek & & & \\
\hline & Toplumdaki düzeni sağlamak. & $\sqrt{ }$ & $\sqrt{ }$ & $\sqrt{ } \sqrt{ }$ \\
\hline & Hayata uyum sağlamak. & & & $\sqrt{ }$ \\
\hline & Özgüven kazanmak & & $\sqrt{ } \sqrt{ }$ & $\sqrt{ }$ \\
\hline & Kendini geliştirmek & $\sqrt{ }$ & $\sqrt{ }$ & $\sqrt{ }$ \\
\hline & Değişim & $\sqrt{ } \sqrt{ }$ & & \\
\hline & Değerleri aktarmak & $\sqrt{ } \sqrt{ }$ & & \\
\hline
\end{tabular}

Bulgular doğrultusunda X kuşağı (55-40 yaş) katılımcıların eğitim tanımlarına bakıldığında eğitimi tecrübe, süreç, görev, değişim ve değerler olarak tanımladıkları görülmektedir. Y kuşağı (39-41 yaş) katılımcılar eğitimi bilgi, aile ve arkadaşlardan (çevreden) öğrendiklerimiz, gelişim, istendik davranış geliştirme ve süreç olarak tanımlamaktadır. Z kuşağı (20 yaş ve altı) ise eğitimi bilgi, aile ve arkadaşlardan 
(çevreden) öğrendiklerimiz, gelişim, tecrübe istendik davranış geliştirme olarak tanımlamaktadır. Katılımcıların eğitimin tanımına ilişkin ifadelerinde X50'nin "Ĕ̆itim değiştirmedir, insanlar değiştirmeye yönelik yapılan faaliyetlerdir." ve X55' in "Ĕ̆itim, değerleri yeni nesillere aktarmaktır." şeklindeki ifadeleri $X$ kuşağının eğitimi değişim ve değerler çerçevesinde tanımladıklarını göstermektedir. X46 eğitimin çok yönlü bir süreç olduğunu "Eğitim bireyin toplumdaki konumunun kişisel, sosyal, psikolojik yönünün kapsayan çok yönlü bir süreçtir." şeklinde ifade etmiştir. X42 eğitimi, "Bireyin toplumdaki gereksinimlerini giderebilmesi için alması gereken değerler" olarak tanımlamıştır. Y kuşağı katılımcıların eğitimi aile, okul ve arkadaş çevresinde öğrenilenler olarak tanımladıkları görülür. Y23'ün "Eğitim aileden, okuldan çevreden öğrendiklerimizdir ilk olarak ailede başlar, temeller ailede atılır." ve Y30'un "Eğitimde toplumun, ailenin, arkadaşların çevrenin ve bütün sosyal hayatın çok etkisi vardır." şeklindeki ifadeleri örnek ifade olarak gösterilebilir. Z17' nin "Eğitim öğrencilere bilgi vermektir." ve Z15'in "Eğitimi tecrübe olarak görüyorum." ifadelerinden Z kuşağının eğitimi bilgi ve tecrübe olarak yorumladıkları anlaşılmaktadır. X46 eğitim ve öğretimin farklı olduğunu "Ĕğitim öğretimi de kapsayan ama çok daha bütüncül bir yapıdır." şeklinde ifade etmiştir. Ayrıca X46 "Matematik, fizik, tarih, coğrafya bunlar eğitimin parçalarıdır, insani özellikler, toplumsal ilişkiler bunlar eğitim aracilı̆̆ıyla olur." ifadesiyle eğitim ve öğretimin ayrımını belirtmiştir. Katılımcıların eğitimin içeriğine yönelik ifadelerine göre üç kuşağın tanımlarında da deneyim ve tecrübeler vurgusu yer alırken Y kuşağının buna ek olarak yaşam boyu edinilen bilgi ve deneyimleri ve $Z$ kuşağının ise toplumsal davranış normlarını bu içeriğe dahil ettiği görülmüştür. Z17'nin eğitim içeriğine yönelik “Öğrencilerin bir toplumda nasıl davranmalar gerektiğini öğretir." şeklindeki ifadesi bu açıdan önemli ve dikkat çekicidir. Katılımcıların hemfikir oldukları eğitimin içeriğinin deneyim ve tecrübelerden oluştuğuna dair Y30'un "Başımıza gelen olaylardan yaşadığımız hayatımız boyunca elde ettiğimiz tecrübelerle geliştirebildiğimiz, bazen pişmanliklar yaşadığımız, bazen mutlu olduğumuz bir zaman dilimidir." ifadesi örnek olarak gösterilebilir. Y ve Z kuşağındaki katılımcıların eğitimi yaşam boyu devam eden bir olgu olarak algıladıkları söylenebilir. Y23, Y30, Z15 ve Z20 eğitimin yaşam boyu bir süreç olduğunu vurgulamışlardır. Bu ifadelerden Y23'ün "İnsanların hayatı boyunca yeni bir şeyler öğrenerek geliştirdiği iyi yöne doğru 
kendisini adım atarken bulmak istediği bir süreçtir." ifadesi örnek olarak gösterilebilir. Katılımcıların eğitimin amacına yönelik ifadelerine bakıldığında, $X$ kuşağından katılımcıların eğitimin amacını değişim ve değerler, $Y$ ve $Z$ kuşağındaki katılımcıların ise bu amacı kendini geliştirme ve özgüven kazandırma kavramlarıyla ilişkilendirdikleri söylenebilir. X46 eğitimin toplumsal gelişimdeki rolünü vurgulayarak, eğitimin amacını "Bireysel ve toplumsal gelişimin bir sürece dönüşümü eğitimle olur" şeklinde ifade etmiştir. X55 ise eğitimin amacın "toplumdaki değişimlere ve hayata uyum sağlama" olarak ifade etmişdir. X50 eğitimin amacını "Değerlerimizi yeni nesillere aktarmak" olarak ifade etmiştir. Y30 ve Z20 eğitimin amacını "Kendini geliştirmek de bir eğitimdir." (Y30), "Eğitim kendini geliştirilmek üzerine olumlu yöne doğru izlenen yoldur." (Z20) şeklinde ifade etmişlerdir. Y17 ise "Bireyleri eğiterek toplumun düzeni sağlanır" ifadesi ile eğitimin amacının toplumda düzeni sağlamak olduğunu belirtmiştir.

X, Y, Z Kuşaklarının Öğretmene Yönelik Algıları: Katılımcıların öğretmene ilişkin algıları mesleki özellikler ve davranışlar temalarına göre incelenmiştir. Mesleki özellikler teması sınıf yönetimi, alan bilgisi, pedagojik bilgi alt temalarında, davranış teması ise kişilik özellikleri ve demokratik özellikler alt temalarında incelenmiştir. 
Tablo 4. X, Y, Z Kuşağı Katılımcıların Öğretmene İlişkin Algıları

\begin{tabular}{|c|c|c|c|c|c|}
\hline & Tema & Kodlar & $\begin{array}{l}X(55-40 \text { yaş }) \\
(n=2)\end{array}$ & $\begin{array}{l}Y(39-31 \text { yaş }) \\
(n=4)\end{array}$ & $\begin{array}{l}Z(20 \text { yaş ve } \\
\text { altı) } \\
(n=5)\end{array}$ \\
\hline \multirow{32}{*}{ 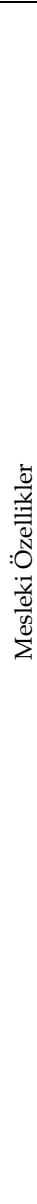 } & \multirow{8}{*}{ Sınıf Yönetimi } & İyi bir gözlemci & $\sqrt{ }$ & $\sqrt{ }$ & $\sqrt{ }$ \\
\hline & & İyi bir ses tonu & & $\sqrt{ }$ & \\
\hline & & İlgili & & & $\sqrt{ }$ \\
\hline & & Dersi iyi anlatan & & & $\sqrt{ } \sqrt{ } \sqrt{ }$ \\
\hline & & Sınıf hâkimiyeti & & $\sqrt{ } \sqrt{ }$ & $\sqrt{ } \sqrt{ }$ \\
\hline & & Çocukları seven & & $\sqrt{ }$ & \\
\hline & & Otorite sahibi olan & & $\sqrt{ } \sqrt{ } \sqrt{2}$ & $\sqrt{ } \sqrt{ }$ \\
\hline & & İletişimi iyi olan & & $\sqrt{ }$ & \\
\hline & \multirow{4}{*}{ Alan bilgisi } & Birikimli & $\sqrt{ }$ & & $\sqrt{ } \sqrt{ }$ \\
\hline & & İyi alan bilgisi & $\sqrt{ } \sqrt{ }$ & $\sqrt{ }$ & $\sqrt{ }$ \\
\hline & & Kendini geliştirmek & $\sqrt{ }$ & $\sqrt{ }$ & \\
\hline & & Çağa uyumlu olmak & $\sqrt{ } \sqrt{ }$ & & \\
\hline & \multirow{5}{*}{ Pedagojik Bilgi } & Ödev vermeyen & & & $\sqrt{ }$ \\
\hline & & Sinavlarda zorlamayan & & & $\sqrt{ }$ \\
\hline & & Öğrenci seviyesine & & $\sqrt{ }$ & $\sqrt{ } \sqrt{ }$ \\
\hline & & $\begin{array}{l}\text { uygun ders anlatan } \\
\text { Derste aktif yöntemler } \\
\text { uygulayan }\end{array}$ & & $\sqrt{ } \sqrt{ }$ & $\sqrt{ } \sqrt{ }$ \\
\hline & & \multicolumn{2}{|l|}{ Öğrenciye rol model olan $\sqrt{ }$} & $\sqrt{ } \sqrt{ }$ & $\sqrt{ }$ \\
\hline & \multirow{12}{*}{$\begin{array}{l}\text { Öğrenciyle etkileşim } \\
\text { İletişim, Görsellik }\end{array}$} & \multicolumn{2}{|l|}{$\begin{array}{l}\text { Sevecen (Güler yüzlü - } \\
\text { Eğlenceli Kızmayan- } \\
\text { Bağırmayan- Mutlu) }\end{array}$} & $\sqrt{ } \sqrt{ } \downarrow V$ & $\sqrt{ } \sqrt{ }$ \\
\hline & & Duyarlı & & $\sqrt{ }$ & $\sqrt{ }$ \\
\hline & & Disiplinli & $\sqrt{ } \sqrt{ }$ & $\sqrt{ } \sqrt{ }$ & $\sqrt{ }$ \\
\hline & & Sorumlu & $\sqrt{ } \sqrt{ } \sqrt{ }$ & $\sqrt{ } \sqrt{ } \sqrt{ }$ & $\sqrt{ }$ \\
\hline & & İşini seven & $\sqrt{ }$ & $\sqrt{ } \sqrt{ }$ & \\
\hline & & İşini iyi yapan & & & $\sqrt{ }$ \\
\hline & & İçki sigara kullanmayan & & $\sqrt{ } \sqrt{ }$ & \\
\hline & & Güvenilir & & $\sqrt{ } \sqrt{ }$ & \\
\hline & & Sabırlı & & $\sqrt{ } \sqrt{ }$ & \\
\hline & & Fedakâr & & $\sqrt{ } \sqrt{ } \sqrt{ }$ & \\
\hline & & İyi görünümlü (kılık & & $\sqrt{ } \sqrt{ }$ & \\
\hline & & kıyafet düzgün) & & & \\
\hline & & Eşit & & $\sqrt{ } \sqrt{ }$ & $\sqrt{ } \sqrt{ }$ \\
\hline & & Ayrım yapmayan & & $\sqrt{ } \sqrt{ } \sqrt{ }$ & $\sqrt{ } \sqrt{ }$ \\
\hline & & Hoşgörülü & & $\sqrt{ }$ & \\
\hline \multirow{4}{*}{ 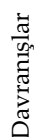 } & Demokratik davranışlar & Empati kuran & & $\sqrt{ }$ & $\sqrt{ }$ \\
\hline & & Mesleğini seven & & $\sqrt{ } \sqrt{ } \sqrt{ }$ & \\
\hline & & Değerlerine bağlı olan & $\sqrt{ }$ & & \\
\hline & & Objektif olan & & $\sqrt{ }$ & \\
\hline
\end{tabular}

Katılımcıların görüşleri incelendiğinde öğretmenlerin mesleki özellikler açısından $Y$ ve $Z$ kuşağındaki katılımcıların sınıf yönetimine dair öğretmenden beklentilerinin benzer olduğu görülmektedir. $Y$ ve $Z$ kuşağında yer alan katılımcilar öğretmenden sınıfa hâkim ve otorite sa- 
hibi olmasını beklemektedir. Y5'in “Öğrenciyle arasında mutlaka bir saygı çerçevesi belli bir ölçü olmalıdır." ve Y20'nin "Sınıf içerisinde otoritesini sağlayan biri olmalı." ifadeleri sinıfta otoriter bir öğretmen beklentisine örnek olarak gösterilebilir. Benzer şekilde Z15'in "Disiplinli, güven sahibi olmalı" ve Z17'nin "İnsanları yönetebilen, stnıfa hakim biri olmalı." şeklinde ifadeleri sınıf yönetimine ilişkin öğretmenden otoriter ve disiplinli olması beklentisine örnek olarak gösterilebilir. Üç kuşağın öğretmenden beklediği ortak özellik ise öğretmenin iyi bir gözlemci olmasıdır. X42'nin bu konudaki görüşü “Bir öğretmenin öğrenciyi tanıması için iyi bir gözlemci olması gerekir." örnek verilebilir. Katılımcılar öğretmenin mesleki özelliklerinden alan bilgisinin olması, çağa uyumlu olması, kendini geliştirmesi ve birikimli olması gerektiği yönünde hem fikir oldukları söylenebilir. X46'nın bu konudaki ifadesinin de "Bir öğretmen gerek şart olarak bulunduğu uzmanlık alanıyla ilgili yeterli olmalıdır, yeter şart olarak ise çă̆ın gerçeklerinden haberdar olan, kişisel gelişimi süreklilik arz eden olmalıdır." bu durumu destekler nitelikte olduğu görülmektedir. Katılımcıların öğretmenlerin mesleki özelliklerinden pedagojik bilgiye yönelik görüşleri içerisinde $\mathrm{Y}$ ve $\mathrm{Z}$ kuşağında ortak olan bazı ifadeler görülmektedir. Bunlar öğretmenin öğrenci seviyesine uygun ders anlatımı, derste aktif yöntemler kullanımı, öğrenciye rol model olması gerektiği yönündeki ifadelerdir. $Z$ kuşağı katılımcıları arasında öğretmenin pedagojik bilgisinin yanında fazla ödev vermemesi ve sınavda zorlamaması gerektiği yönünde görüşler vardır. Z17'nin “Öğretmen sinavları da çok zor yapmamalıdır. Öğretmen anlattığı kadar sormalıdır." ve Z7'in "Çok ödev vermeyen, dersi hızl anlatmayan kızmayan" şeklindeki ifadeleri örnek olarak gösterilebilir.

Katılımcıların görüşlerine göre öğretmenlerin öğrencilere yaklaşımı, etkileşimleri, iletişim becerileri gibi konuları kapsayan özellikler öğretmenin davranışsal özellikleri boyutunda değerlendirilmiştir. $X, Y$ ve $Z$ kuşağ1 katılımcılar öğretmenlerin öğrencileriyle etkileşimlerinde güler yüzlü olmaları, sevecen olmaları, öğrenciye karşı duyarlı ve sorumlu olmaları yönünde ortak görüşler belirttikleri görülmektedir. Z10'un “Bir öğretmen sempatik olmalı, öğrencilerine karşı duyarlı uyumlu, güler yüzlü olmalı" ifadesi örnek bir ifade olarak gösterilebilir. Y kuşağı katılımcıları bu boyutta farklı olarak öğretmenin görsel açıdan kendine dikkat etmesi yönünde kılık kıyafetinin düzenli olması ve iyi görünümlü olması gibi 
görüşe sahip oldukları görülmektedir. Y36'nın "Kıyafet düzeni çok önemli öğretmen görünümüne dikkat etmelidir" şeklinde ifadesi dikkat çekicidir. Y23 ise "İçki ve sigara kullanımının öğrenciler üzerinde çok fazla kötü örnek oluşturduğunu düşünüyorum bunu bir öğretmen kesinlikle yapmamalı" ifadesiyle öğretmenin içki ve sigara kullanmaması gerektiğini vurgulamıştır. X kuşağı katılımcıları ise öğretmenin davranışsal özelliklerini disiplinli, otorite, sorumluluk sahibi ve işini iyi yapması olarak görmektedirler. Bu durum katılımcilardan X46'nın "Etik değerler açısından son derece yüksek sorumluluğu olan bir meslek grubunda olduğu için öğretmen sürekli kendini geliştirmeli ve örnek olmalıdır." şeklindeki ifadeleriyle ortaya konmaktadır.

Öğretmenlerin eşit davranması, ayrım yapmaması, objektif olması, empati kurabilmesi, hoşgörülü olması, değerlerine bağlı olması, mesleğini sevmesi gibi özellikler demokratik özellikler boyutunda değerlendirilmiştir. Y ve Z kuşağı katılımcılarının bu boyuta ilişkin görüşleri incelendiğinde öğretmenin eşit davranan, ayrım yapmayan, objektif olması gerektiği yönünde görüş belirttikleri görülmektedir. Katılımcılardan Y17' nin “Öğretmen öğrencilerine ayn eşitliği sağlamalıdır sadece çalışkanlarla ilgilenmemeli tembel öğrencilerle de ilgilenmelidir.", Y23'ün "Öğretmen kesinlikle erkek/kız ayrımı yapmamalıdır." ve Z15'in "Bir öğretmen her şekilde adil olmalıdır." şeklindeki ifadeleri öğretmenin demokratik davranışlar içerisinde olması gerektiğini gösteren bulgular olarak değerlendirilebilir. X kuşağı katılımcıları öğretmenin değerlerine bağlı olması gerektiği yönünde görüş bildirmişlerdir. Y kuşağı katılımcıları öğretmenin hoşgörülü olması ve empati kurabilmesi gerektiğini vurgulamişlardır. Y32'nin “Öğretmen kendini öğrencisinin yerine koyup düşünebilmeli yani empati yapabilmeli." ifadesi örnek olarak gösterilebilir.

X, Y, Z Kuşaklarının Öğrenciye Yönelik Algıları: X, Y ve Z kuşağ katılımcların öğrenciye ilişkin algıları kişilik özellikler, davranışlar ve beceriler temalarına göre incelenmiştir. 
Tablo 5. X, Y, Z Kuşă̆ı Katılımcıların Öğrenciye İlişkin Algıları

\begin{tabular}{|c|c|c|c|c|}
\hline Tema & Kodlar & $\begin{array}{l}X(55-40 \text { yaş }) \\
(n=2)\end{array}$ & $\begin{array}{l}\mathrm{Y}(39-31 \text { yaş }) \\
(\mathrm{n}=4)\end{array}$ & $\begin{array}{l}Z \text { ( } 20 \text { yaş ve altı) } \\
(n=5)\end{array}$ \\
\hline \multirow{8}{*}{ Kişilik } & Sempatik & & & $\sqrt{ }$ \\
\hline & Uyumlu & & & $\sqrt{ }$ \\
\hline & Saygilı & & & $\sqrt{W} W$ \\
\hline & Disiplinli & & & $\checkmark$ \\
\hline & İlgili & & & $\sqrt{ }$ \\
\hline & Sorumlu & & & $\sqrt{ }$ \\
\hline & Okulu sevmek & & & $\sqrt{ }$ \\
\hline & Öğretmeni sevmek & & $\checkmark$ & 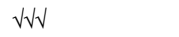 \\
\hline \multirow{13}{*}{ Davranışlar } & Saygilı & v & $\checkmark$ & $\sqrt{ } \mathrm{V}$ \\
\hline & $\begin{array}{l}\text { Arkadaşlarıyla iyi ilişkiler içinde } \\
\text { olan }\end{array}$ & & & $\sqrt{ } \sqrt{ }$ \\
\hline & Sorumlu & $\sqrt{ }$ & $\sqrt{ } W$ & $\sqrt{ }$ \\
\hline & Güçlü & & & $\sqrt{ }$ \\
\hline & Düşündüğünü ifade eden & $\sqrt{ }$ & & $\sqrt{ }$ \\
\hline & Kllık kiyafeti düzgün & & & $\sqrt{ }$ \\
\hline & İstekli & & $\sqrt{ }$ & \\
\hline & Canlı & & $\sqrt{ }$ & \\
\hline & Terbiyeli & & $\sqrt{ }$ & \\
\hline & Sevecen & & v & \\
\hline & İstekli & & v & \\
\hline & Çalışkan & $\sqrt{ }$ & $\downarrow W W$ & \\
\hline & Duygulu & & $\sqrt{ }$ & \\
\hline \multirow{8}{*}{ Beceriler } & Başarılı & & & $\sqrt{ }$ \\
\hline & İletişimi iyi & $\sqrt{ }$ & $\sqrt{ }$ & $\sqrt{ }$ \\
\hline & Girişken & & $\sqrt{ }$ & $\sqrt{ }$ \\
\hline & Zamanı iyi kullanan & & $\sqrt{ }$ & \\
\hline & Sosyal sorumluluk & $\sqrt{ }$ & & \\
\hline & Hedefi olan & $\sqrt{ }$ & & \\
\hline & Bilinçli & $\sqrt{ }$ & & \\
\hline & Farkındalık sahibi & $\sqrt{ }$ & & \\
\hline
\end{tabular}

Katılımcılar öğrencilerin kişisel özelliklerini; sempatik, öğretmeni seven, okulu seven, uyumlu, saygıll, disiplinli, ilgili olma açısından değerlendirmişlerdir. Z kuşağ 1 katılımcılarda genel olarak öğrenci kişisel özellikleri ile ilgili genel olarak sempatik, öğretmeni seven, okulu seven, uyumlu, saygılı, disiplinli olması yönünde görüşler hâkimdir. Z10'un "Bir öğrenci sempatik ve uyumlu olmalıdır", Z17'nin "Bir öğretmen bir öğrenciye ne kadar yumuşak davranırsa davransin o öğretmene karşı saygılı olmalıdır" ve Z20'nin "Öğrenci, öğrenmeye istekli ve edindiği bilgileri hayatına uyarlayabilen bir nitelikte olmalıdır." şeklindeki ifadeleri öğrencinin kişisel özelliklerine yönelik ifadeler olarak dikkat çekmektedir. Y kuşağ 1 katılımcılarının bu boyutta öğrencilerin öğretmeni sevmesi yönünde görüş belirttikleri görülmektedir. Y36'nın “Öğrenci en başta öğretmenini, dersini sevmeli, dinlemeli" şeklinde ifadesi örnek olarak 
gösterilebilir. X kuşağı katılımcıların ise öğrencilerin kişisel özelliklerine yönelik herhangi bir görüş belirtmedikleri görülmektedir.

$X, Y$ ve $Z$ kuşağı katılımcıların öğrencilerin davranışsal özelliklerine yönelik algıları ele alındığında, öğrencilerin saygılı, sorumlu, arkadaşlarıyla iyi ilişkileri olan, güçlü, çalışkan, terbiyeli, istekli ve kılık kıyafetinin düzenli olması gerektiğini belirtmişlerdir. $X, Y$ ve $Z$ kuşakları öğrencilerin çalışkan, sorumlu ve saygılı olması yönünde ortak görüşe sahiptir. Z17'nin "Öğrenci kulık kıyafetine dikkat etmeli okul formasına uyumlu olmalı, forma dışında bir şeyler giymemelidir." ve Y30'un "Öğrenci sayg̨ll, zamanın iyi kullanan, terbiyeli, sevecen olmalı." ifadeleri örnek olarak gösterilebilir. Y kuşağı katılımcıları öğrencilerin istekli, terbiyeli, çalışkan ve duygulu olması gerektiğini vurgulamışlardır. Katılımclardan Y21 bu durumu "Öğrenci en başta derse katılmalıdır, çalışmalıdır, öğretmenine saygllı olmalıdır, ödevlerini zamanında yapmalıdır." şeklinde ifade etmiştir. Z20' nin "Öğrenci canlı ve enerjik olmalı. Çünkü sıkılgan bir öğrenci zaten dersten zevk almaz, dersi dinlemek istemez." şeklindeki ifadesi öğrenciden beklenen kişilik özelliklerinin canlı, hareketli olması gerektiği yönündedir. X kuşağı katılımcıları öğrencilerden bekledikleri kişilik özelliklerini sorumluluk ve çalışkan olma olduğunu belirtmişlerdir. Katılımcılardan X50 “Ö renci sorumluluk sahibi olmalıdır." şeklinde ifade ederken, X55 "Öğrenci verilen görevi yapar, derse zamanında gelir, derslerinde başarılı olmak için gayret gösterir." şeklinde ifade etmiştir.

$X, Y$ ve $Z$ kuşağı katılımcıları öğrencide olması gereken becerileri iletişim, girişkenlik, zamanı iyi kullanma, sosyal sorumluluk, hedef koyan, bilinçli olmak olarak sıralamışlardır. Y ve Z kuşağında öğrencilerin sahip olması gereken becerilerden iletişim ve girişkenlik becerilerinin ortak olduğu görülmektedir. Katılımcılardan Z15, öğrencinin sahip olması gereken beceriyi "Her ortamda kendi düşüncesine, fikrine sahip çıkmalı, özgürce ifade edebilmelidir." olarak ifade etmiştir. Z10 ise "Düşüncelerini sadece sözle değil davranışlarına da aktarabilen biri olmalıdır." ifadesi ile iletişim becerisinin önemini vurguladığı söylenebilir. Öğrencilerin becerilerine yönelik Y kuşağı katılımcıları daha fazla görüş bildirdiği görülmüştür. Y kuşağı katılımcıları öğrencilerin iletişim ve girişkenlik becerilerine vurgu yaparken, X kuşağı katılımcıların öğrencilerin sosyal sorumluluk, bilinçli olma ve farkındalık becerilerinin önemli olduğunu belirtmişlerdir. X42'nin "Kendini ifade edebilen, ne istediğini bilen, bir amacı olan birey olma- 
lı", X50' nin "Öğrencinin akademik başarısı yanında sosyal sorumluluk, çevresine karşı duyarlılığı da önemlidir." ve X55'in "Öğrenci yaşadığı çevreye, topluma karşı sorumludur bunun farkında olan bir nesil yetiştirmek önemlidir." ifadeleri örnek olarak gösterilebilir.

\section{Tartışma ve Sonuç}

$\mathrm{Bu}$ çalışmada farklı yaş gruplarındaki kişilerin eğitim, öğretmen ve öğrenciye yönelik algılarının kuşaklar arası farklılıklara göre tanımlanması amaçlanmıştır. Bu bağlamda $X, Y, Z$ kuşağında yer alan katılımcların görüşleri doğrultusunda eğitim, öğretmen ve öğrenciye yönelik algıları belirlenmiştir.

Katılımcıların eğitime yönelik algıları eğitimin tanımı, eğitimin amacı ve eğitimin içeriği olarak belirlenmiştir. Katılımcların eğitimin tanımına yönelik görüşleri incelendiğinde $X$ kuşağı katılımcıları eğitimi tecrübe, süreç, görev, değişim ve değerler olarak tanımlarken, $Y$ kuşağ 1 katılımcıları bilgi, çevreden öğrendiklerimiz, gelişim ve istendik davranış değiştirme olarak tanımlamışlardır. $X$ kuşağı eğitimi, eğitimin toplumla olan ilişkisi ve topluma uyum sağlama amacı olarak ifade etmişlerdir. $X$ kuşağın eğitim tanımında toplumsallık vurgusu ön plandayken, $Z$ kuşağı katılımcıları eğitimi, tecrübe, deneyim ve yaşantılar sonucu edinilen bilgi olarak tanımlamışlardır. $Y$ ve $Z$ kuşağı katılımclarının eğitim tanımlarındaki bilgi, çevreden öğrenilenler ve istendik davranış değiştirme süreci ortak kavramlar olduğu görülmektedir. Titiz (2000) araştırmasında eğitimin yeni tanımını şöyle yapmıştır: "Eğitim, değişen durumların gerektirdiği bilgi ve becerileri yardımsız öğrenebilme ve bunları yaşamın özel durumlarına uygulayabilme sanatının kazanılmasıdır." Bu tanımdaki bireysellik vurgusu $\mathrm{Y}$ ve $\mathrm{Z}$ kuşağı katılımcıların eğitim algılarında görülmektedir.

Eğitimin içeriği $X$ kuşağ ${ }_{1}$ için deneyim ve tecrübeler, $Y$ kuşağ 1 için yaşam boyu edinilen düşünceler ve görüşler, $Z$ kuşağ 1 için ise aileden, çevreden, öğretmenlerden öğrenilenler ve toplumdaki davranışlarımız olarak görülmektedir. 21. yüzyıl eğitimi, öğrenme ortamı olarak tüm çevresini kullanan, öğrencilerin ilgi ve ihtiyaçları doğrultusunda bireyselleştirilmiş eğitimden yararlanabileceği ortamlardan oluşturur (Oktay, 2001, s.21). Bu nedenle eğitim, zaman, mekân ve programlar yönünden 
sınırsız denilebilecek düzeye ulaşabilir (Ensari, 2001, s.53). 21. yüzyıl eğitim anlayışındaki sınırsızlık ya da bireysellik vurgusu $Y$ ve $Z$ kuşağının eğitim tanımlarında da görülmektedir.

Eğitimin amacını $X$ kuşağı katılımcıları deneyim ve değerler, $Y$ kuşağ 1 toplumdaki düzeni sağlamak ve kendini geliştirmek, $Z$ kuşağ 1 ise toplumdaki düzeni sağlamak, hayata uyum sağlamanın yanında kendini geliştirmek ve özgüven sağlamak olarak ifade etmişlerdir. Bu bulgu Hesapçığlu (2009, s.139)'nun; "eğitimin amact özgür ve adil insan yetiştirmektir. Ĕ̆itim etkinliklerinde sadece bireyi ya da toplumu değil, ikisini de birleştiren özgür ve adil bir hedef olmalıdır." görüşüyle benzerlik göstermektedir.

Katılımcıların öğretmene yönelik algılarında öğretmenin mesleki özellikleri ve davranışları olduğu görülmektedir. Öğretmenlere yönelik algıların belirlenmesi amacıyla yapılan araştırma sonuçları görsel, davranışsal ve mesleki boyutların etkili olduğunu gösterir. Öğretmenin mesleki alan bilgisi, öğretme arzusu, ifadelerinin netliği, öğretim yöntemlerindeki çeşitlilik, geri bildirim vermesi, öğrenci katılımını desteklemesi ve dersin planlanması gibi faktörlere bağlıdır (Coats, Swierenga ve Wickert, 1972; DenBrok, Brekelmans ve Wubbels, 2004). Bu bağlamda öğretmenin mesleki özelliklerinin onun mesleki becerileriyle doğrudan ilişkili olduğu söylenebilir (Ölçüm ve Polat, 2016). Araştırma bulguları incelendiğinde öğretmenlerden beklenen mesleki özelliklerin sinıf yönetimi, alan bilgisi ve pedagojik bilgisi olduğu şeklinde değerlendirilebilir. Öğretmenden beklenen davranışların ise öğrenciye yönelik davranışlar ve demokratik davranışlar şeklinde olduğu görülmüştür. Katılımcıların öğretmenin mesleki özellikleri ile ilgili algıları kuşaklar arası farklılık açısından incelendiğinde, $\mathrm{Y}$ ve $\mathrm{Z}$ kuşağı katılımcılarının öğretmenlerin sınıfa hâkim, otoriter olmalarını beklediği görülmektedir. Alanyazındaki araştırmalar incelendiğinde $X$ ve $Y$ kuşağ bireylerinin liderliğe verdikleri önem noktasında da benzer durum söz konusudur. Liderlik vasfına sahip olmak $Y$ kuşağı üyeleri tarafından, $X$ kuşağının üyelerine göre daha önemli bulunmaktadır (Akdemïr, Konakay, Demirkaya, 2013). Aynı zamanda $\mathrm{Y}$ kuşağına mensup bireyler çalışma ortamlarında da yöneticilerinden mentor ya da rol model olmaların talep etmektedir (Gürsoy Maier ve Chi, 2013, s.45). 
Y kuşağı katılımcları sınıf yönetiminde öğretmenin ses tonu ve iletişimin de etkili olduğunu, $\mathrm{Z}$ kuşağı katılımcıları ise öğretmenin dersi iyi anlatmasının önemli olduğunu belirtmiştir. Keleş'e (2011) göre Y ve Z kuşağı özelliklerinden biri de esnek bir çalışma ortamı isteği içinde olmalarıdır. Bu durumda otorite olma ve sinıfa hakim olma beklentisi kuşakların bu özelliğine ters düşen bir durumdur.

Öğretmenlerden beklenen davranışsal özellikler kuşaklar bazında değerlendirildiğinde $X$ kuşağı katılımcıların öğretmenden beklediği özellikler disiplin ve sorumluk iken $\mathrm{Y}$ ve $\mathrm{Z}$ kuşağı katılımcılar için güvenilir, sabırlı ve sevecen olma gibi özelliklerdir. İnsanların davranış tarzları ve iletişim becerileri, nasıl algılandıklarına ilişkin temel göstergelerdir (Bulduklu, 2015). Etkileşim ve iletişim, öğretmenlik mesleğinin doğasının temel yeterlikleri olarak nitelendirilebilir. Dolayısıyla, öğretmenlerin bu yeterliklere ilişkin sergileyeceği davranışlar insanların hafızasında şekillenen öğretmen imajını etkiler. Ker-Dinçer'e (2000) göre iletişim becerileri sözel, yazılı ve sözsüz iletişimi, iletişim tarzları ise kişilerin iletişim esnasında sergiledikleri genel davranış kalıplarını ifade etmektedir. Cuickshank, Bainer ve Metcalf'a göre (1995), öğrencileri ile etkili iletişim kurma becerilerine sahip olan, onların güvenini kazanan, onlara karşı hoşgörülü olan ve onları cesaretlendiren öğretmenler, öğrencilerin saygısını kazanır, aynı zamanda onların akademik başarılarına katkı sağlar. Bu noktadan hareketle, öğretmenlerin öğrencilere yönelik yapıcı tutumlarının, onlarla kurduğu etkili iletişimin, etkileşimin ve ılımlı davranışlarının öğretmen imajının oluşumunda kritik öneme sahip olduğu söylenebilir.

$X$ kuşağı katılımcıların öğretmenden beklediği demokratik davranış değerlerine bağlı olmasıyken, Y ve Z kuşağının öğretmenden beklediği demokratik davranışlar eşitlik, empati ve hoşgörülü olmasıdır. Y kuşağının lider tercihleri arasında demokratik lider tipi öncelikli olarak gelmektedir (Akdemïr, Konakay, Demirkaya, 2013). Y kuşağ katılımcılar öğretmenin sahip olması gereken özellikleri; dersi iyi anlatması ve sinavda zorlamaması olarak ifade etmiştir. Cumhuriyet Dönemi ile birlikte öğretmene yüklenen toplumsal liderlik ve kanaat önderliği gibi rollerin (Türk Eğitim Derneği, 2009) 1980'lerden sonra sınav ve başarı odaklı eğitim sistemine bağlı olarak kaybolması ve öğretmenlik mes- 
leğinin teknisyen öğretmen olarak algılanması olarak belirtilebilir (TEDMEM, 2014, Ünsal 2018).

Nayir ve Çınkır (2017) Türkiye'de kuşaklararası eğitim farklılıklarını inceledikleri araştırmalarında öğretmen öğrenci ilişkileri boyutunda önceden öğretmenin daha saygın olduğu ve öğrenci üzerinde yaptırım gücünün fazla olduğu ancak son zamanlarda artık öğretmene yeterince sayg1 duyulmadığı sonucuna varmışlardır. Bu durumun oluşmasında öğretmenlik mesleğinin saygınlığının yitirilmesinin etkili olduğu söylenebilir. Öğretmenler son zamanlarda özellikle medyanın ve Milli Eğitim Bakanlığı'nın kendilerine yeterince değer vermediğini düşünmektedir (Özoğlu, Gür ve Altınoğlu, 2013). Bu durum aynı zamanda toplumun öğretmenlere verdiği önemin bir göstergesidir. Dolayısıyla, öğretmenliğin toplumda giderek saygınlığını yitirmesinin, okulda öğretmen- öğrenci ilişkilerine de olumsuz olarak yansıdığ söylenebilir.

$X, Y$ ve $Z$ kuşağı katılımcıların öğrenciye ilişkin algıları kişilik özellikler, davranışlar ve becerilerdir. Katılımcılar öğrencilerin kişisel özelliklerini; sempatik, öğretmeni seven, okulu seven, uyumlu, saygılı, disiplinli, ilgili olma açısından değerlendirmişlerdir. $Z$ kuşağı katılımcları için öğrenci sempatik, öğretmeni seven, okulu seven, uyumlu, saygılı ve disiplinli olmalıdır. Y kuşağı için öğrencilerin öğretmeni sevmesi önemli bir özelliktir.

$X, Y$ ve $Z$ kuşağı katılımcıların öğrencilerin davranışsal özelliklerine yönelik algıları ele alındığında öğrencilerin saygılı, sorumlu, arkadaşlarıyla iyi ilişkileri olan, güçlü, çalışkan, terbiyeli, istekli ve kılık kıyafetinin düzenli olması gerektiğini belirtmişlerdir. $Y$ kuşağı katılımcılar öğrencilerin istekli, terbiyeli, çalışkan ve duygulu olması gerektiğini, X kuşağı katılımcılar ise öğrencilerden bekledikleri kişilik özelliklerini sorumluluk ve çalışkan olma olarak belirtmişlerdir. Yapılan araştırmalar Y kuşağı olarak adlandırılan kuşağın önceki kuşaklara göre daha pratik, dinamik ve daha sonuç odaklı bir kuşak olduğunu göstermiştir (Savaş ve Karataş, 2019). Bu kuşağın üyeleri önceki kuşaklardan daha sabırsız, daha hirslı ve sadakat duygusu daha zayıf bir kuşak olarak adlandırılmıştır (Kuyucu, 2014).

$X, Y$ ve $Z$ kuşağı katılımcıların öğrencilerin becerilerine yönelik algıları ele alındığında; öğrencilerin iletişim, girişkenlik, zamanı iyi 
kullanma, sosyal sorumluluk, hedefi olan ve bilinçli olması gerektiğini belirtmişlerdir. $\mathrm{Y}$ ve $\mathrm{Z}$ kuşağında öğrencilerin sahip olması gereken becerilerden iletişim ve girişkenlik becerilerinin ortak olduğu görülmüştür. Y kuşağı katılımcılar öğrencilerin iletişim, girişkenlik, becerilerine vurgu yaparken, $\mathrm{X}$ kuşağ 1 katılımcilar öğrencilerin sosyal sorumluluk, bilinçli olma, farkındalık becerilerinin önemli olduğunu belirtmişlerdir. Y kuşağının karakteristik özellikleri var oldukları kültürün sosyal ve ekonomik koşullarına göre değişim göstermekle birlikte, en belirgin özellikleri teknolojiye son derece hâkim bir kuşak olmaları internet ve medya ile büyümüş olmalarıdır (Kuyucu, 2017).

Araştırma sonucunda X, Y, Z kuşağında yer alan katılımcıların eğitim, öğretmen ve öğrenciye yönelik algıları belirlenmiştir. Katılımcıların eğitim algıları inclendiğinde; $X$ kuşağı eğitimi, tecrübe ve deneyim olarak tanımlarken, $Y$ kuşağının aile, okul ve arkadaş çevresinde öğrenilenler olarak, $\mathrm{Z}$ kuşağının ise toplumdaki davranışlarımız olarak tanımladığı tespit edilmiştir. Kuşakların öğretmen algıları incelendiğinde; $X$ kuşağ 1 öğretmeni disiplinli ve sorumlu, Y kuşağı güvenilir ve sabırlı, $Z$ kuşağı ise güvenilir, sabırlı ve sevecen olarak tarif etmiştir. Katılımcıların öğrenci algıları incelendiğinde; $X$ kuşağ1 öğrenciyi çalışkan ve sorumlu olarak ifade ederken, Y kuşağ1 öğrencinin istekli, terbiyeli, çalışkan ve duygulu olması gerektiğini, Z kuşağı ise öğrencinin saygılı ve disiplinli olması gerektiğini ifade etmiştir.

$\mathrm{Bu}$ çalışmada genel sonuçlar ortaya koyup, neden-sonuç ilişkileri kurmanın aksine, araştırma konusuyla ilgili öğelerin derinlemesine tanımlanması ve anlaşılması amaçlanmış ve bu yönde genellemeler yapmak yerine kuramsal önermelerde bulunulmuştur. Bu araştırma, başta eğitim kavramı olmak üzere, okullardaki en önemli aktörler olarak nitelendirilebilecek olan öğretmen ve öğrencilere yönelik farklı kuşakların ne düşündüğünü; bu kavramları nasıl algıladıklarını incelemeyi amaçlamış ve bu doğrultuda bir dizi sonucu ortaya koymuştur. Bu noktada bu sonuçların, karar vericilere, okul yöneticilerine ve öğretmenlere okul bileşenleri hakkında farklı kuşakların ne düşündüğü hakkında fikir verebileceği düşünülmektedir. Kuşakların eğitime, öğretmen ve öğrenciye ilişkin bakış açları arasındaki farklılıklar göz önünde bulundurulduğunda, konu ile ilgili farklı kavramlar üzerinde de araştırmalar 
yapılması önerilmektedir. $\mathrm{Bu}$ araştırmada veriler sınırlı sayıda katılımcıdan nitel yöntem kullanılarak elde edilmiştir. Bu bağlamda nicel veya nitel ve nicel yöntemin birlikte kullanıldığı karma araştırma yöntemleriyle daha geniş̧ kitlelere ulaşılarak konu ile ilgili daha derinlemesine araştırmalar yapılabilir. 
EXTENDED ABSTRACT

\title{
Education, Teacher and Student Perceptions of Generations $X, Y$ and $Z$
}

\author{
* \\ Canan Tunç Şahin- Selçuk Turan- Oğuzhan Karadeniz \\ Zonguldak Bülent Ecevit University
}

Characteristics arising from the differences between generations also affect individuals' perspectives on events, phenomena and concepts. Parallel to the changes and transformations in the society, the perceptions of individuals from different generations living in the society towards education also change (Özoğlu, Gür, \& Altınoğlu, 2013). When the literature is examined, there are few studies examining the perceptions of intergenerational education in Turkey (Nayır \& Çınkır, 2017). Studies generally focus on intergenerational value differences (Aygün \& İmamoğlu, 2002; Bowman, 2010; Morsümbül, 2014; Kaya, 2013), intergenerational conflict (Arslan \& Polat, 2016) and the place of generations in business life (Adıgüzel, Batur and Ekşili, 2014). When these studies are examined, it can be said that intergenerational value differences are reflected in education and the meaning attributed to teachers and students has changed accordingly (Aygün \& İmamoğlu, 2002; Bowman, 2010; Kaya, 2013; Morsümbül, 2014). Considering that economic, political, social and technological developments change and shape the lifestyles of generations, it is very important to examine the education, teacher and student perceptions of different generations living in the society. The aim of this research is to determine the education, teacher and student perceptions of individuals in $X, Y, Z$ generations. In order to make in-depth determinations for the determined purpose, the following sub-problems were determined.

1. What are the perceptions of $X, Y, Z$ generations towards education?

2. What are the perceptions of $X, Y, Z$ generations towards teachers?

3. What are the perceptions of $X, Y, Z$ generations towards students?

With this study, it has been revealed how the concepts of education, teacher and student are perceived and interpreted through three different generations defined in the literature as $\mathrm{X}$ generation (55-40 years 
old), Y generation (39-41 years old) and Z generation (20 years and under).

\section{Method}

Pattern of the Research: The phenomenology design, one of the qualitative research methods, was adopted in the study.

Participants: In this study, which was prepared by targeting $\mathrm{X}, \mathrm{Y}$ and $\mathrm{Z}$ generations, a group of participants focused on birth years was formed. Each participant selected for the purpose of the research is expected to belong to a generation that is the subject of the research. The research was conducted with a total of 14 people, 4 from the $X$ generation, 5 from the $\mathrm{Y}$ generation, and 5 from the $\mathrm{Z}$ generation. The participants were informed about the research before participating in the research and participated in the research voluntarily. Ethical approval of the study was obtained from the Ethics Committee of Zonguldak Bülent Ecevit University (2021/76). The names of the participants were kept confidential in accordance with ethical principles, and nicknames representing the generation and age of each participant were given to each participant.

Data collection tool: Research data were collected through a semistructured interview form.

\section{Analysis of Data}

In the research, the data were analyzed by content analysis technique. The principles of credibility, transferability and consistency were determined to ensure the validity and reliability of the research (Lincoln \& Guba, 1985).

\section{Result}

In line with the opinions of the participants in the $\mathrm{X}, \mathrm{Y}, \mathrm{Z}$ generation, their perceptions of education, teachers and students were determined. 
The perceptions of the participants about education were examined according to the themes of definition of education, content of education and purpose of education. When the definitions of education of the $X$ generation (55-40 years) participants are examined, it is seen that they define education as experience, process, duty, change and values. Y generation (39-41 years old) participants define education as knowledge, learning from family and friends (environment), development, development of desired behavior and process. Generation Z (20 years and under) defines education as knowledge, learning from family and friends (environment), development, experience and desired behavior development.

The perceptions of the participants about the teacher were examined according to the themes of professional characteristics and behaviors. The theme of professional characteristics was examined under the subthemes of classroom management, content knowledge, and pedagogical knowledge, and the theme of behavior was examined under the subthemes of personality traits and democratic features. When the views of the participants are examined, it is seen that the teachers' expectations from the teacher about classroom management of the $\mathrm{Y}$ and $\mathrm{Z}$ generation participants are similar in terms of professional characteristics. Participants in the $\mathrm{Y}$ and $\mathrm{Z}$ generation expect the teacher to be dominant and authoritative in the classroom. Participants agree that the teacher should have field knowledge, be compatible with the age, develop himself, and be cumulative. Among the participants' views on pedagogical knowledge from the professional characteristics of teachers, there are some expressions common to the $\mathrm{Y}$ and $\mathrm{Z}$ generation. These are statements that the teacher should lecture appropriate to the student's level, use active methods in the lesson, and be a role model for the student. Among the $\mathrm{Z}$ generation participants, there are opinions that the teacher should not give too much homework and should not force it in the exam in addition to his pedagogical knowledge. The characteristics such as the equal treatment of teachers, being objective, being able to empathize, being tolerant, being loyal to their values, and loving their profession were evaluated in the dimension of democratic characteristics.

The participants' perceptions of the student were examined according to the themes of personality traits, behaviors and skills. Participants 
evaluated personal characteristics of students in terms of being sympathetic, loving the teacher, loving the school, being compatible, respectful, disciplined, and interested. In general, the opinions of the $\mathrm{Z}$ generation participants on the personal characteristics of the students are that they should be sympathetic, loving the teacher, loving the school, harmonious, respectful and disciplined. Considering the perceptions of the $X, Y$ and $\mathrm{Z}$ generation participants regarding the behavioral characteristics of the students, they stated that the students should be respectful, responsible, have good relations with their friends, be strong, hardworking, well-mannered, willing, and have a regular dress code. $\mathrm{X}, \mathrm{Y}$ and $\mathrm{Z}$ generation participants listed the skills that a student should have as communication, assertiveness, good use of time, social responsibility, goal setting and being conscious. It has been seen that the skills of communication and assertiveness, which are the skills that the students of the $Y$ and $\mathrm{Z}$ generation should have, are common.

\section{Kaynakça/Referances}

Adıgüzel, O., Batur, H. ve Ekşili, N. (2014). Kuşakların değişen yüzü ve Y kuşağı ile ortaya çıkan yeni çalışma tarzı: Mobil yakalılar. Süleyman Demirel Üniversitesi Sosyal Bilimler Enstitüsü Dergisi, 19, 165-182.

Akdemir, A. (2012), İşletmeciliğin temel bilgileri. İstanbul: Ekin Basım Yayın Dağıtım.

Arslan, Y. ve Polat, S. (2016). Eğitim örgütlerinde kuşaklar arası çatışma: Nedenleri ve başa çıkma yaklaşımları. Ahi Evran Üniversitesi Kırşehir Ĕ̆itim Fakültesi Dergisi, 17(1), 263-282.

Aydin, I.., Demir, T., G. ve Erdemli, O. (2015). Teacher's views regarding the social status of the teaching profession. Anthropologist, 22(2), 146-156.

Aygün, Z. K. ve İmamoĝlu, E. O. (2002). Value domains of turkish adults and university students. The Journal of Social Psychology, 142(3), 333351.

Berkup, S. B. (2014). Working with generations $X$ and $Y$ in generation $Z$ period: Management of different generations in business life. Mediterranean Journal of Social Sciences, 5(19), 218-229.

Bowman, D. M. (2010). The effect of value differences in workplace motivation: A study comparing worker value piorities across generations and gender. (Unpublished Doctor Thesis). Capella University, Minnesota. 
Bulduklu, Y. (2015). Imaj yönetimi. Konya: Literatürk Academia Yayınları.

Bütün M. F. ve Güneş A. (2020). Dijital çağda öğretmen olmak. Ahmet Güneş (Der.) Geçmişten ve geleceğe öğretmenlik içinde (s.173-196). Ankara Otto Yayınları.

Büyüköztürk, Ş., Çakmak, E. K., Akgün, Ö. E., Karadeniz, Ş. ve Demirel, F. (2009). Bilimsel araştırma yöntemleri. Ankara: Pegem Yayıncılık.

Celep, C. (2004). Meslek olarak öğretmenlik. Ankara: Anı Yayıncılık.

Coats, W. D., Swierenga, L. ve Wickert, J. (1972). Student perceptions of teachers-A factor analytic study. The Journal of Educational Research, 65(8), 357-360.

Creswell, J. W. (2008). Research design: Qualitative, quantitative, and mixed methods approaches. Thousand Oaks, CA: Sage Publications.

Cruickshank, D. L., Bainer, D. L. ve Metcalf, K. K. (1995). The act of teaching (2nd ed.). Boston: Mc Graw-Hill.

Demirkaya, H., Akdemir, A., Karaman, E. ve Atan, Ö. (2015). Kuşakların yönetim politikası beklentilerinin araştırılması. İşletme Araştırmaları Dergisi, 7(1), 186-204.

DenBrok, P., Brekelmans, M. ve Wubbels, T. (2004). Interpersonal teacher behaviour and student outcomes. School Effectiveness and School Improvement, 15(3-4), 407-442.

Duman, M. Z. (2019). Kuşak çatışması: X ve Z kuşă̆ı üzerine sosyolojik bir çalışma. Ankara: Nobel Yayın Dağıtım.

Ensari, H. (2001), 21. yüzyıl için çağdaş bir yönetim yaklaşımı: Toplam kalite yönetimi. O. Oğuz, A. Oktay, H. Ayhan (Der.), 21. yüzyılda eğitim ve Türk Ĕ̆itim Sistemi içinde (s.151-188). İstanbul: Sedar.

Gürsoy, D., Maier, T. A. ve Chi, C. G. (2008). Generational differences: An examination of work values and generational gaps in the hospitality workforce. International Journal of Hospitality Management, 27(3), 448458.

Gök, F. (2003). Hizmet öncesi ve hizmet içi öğretmen yetiştirme. Öğretmen Yetiştirme ve İstihdamı Sempozyumu. Ankara: Eğitim-Sen Yayınları. 922.

Güler, A., Halıcıoğlu, M. B. ve Taşğın, S. (2013). Sosyal bilimlerde nitel araştırma yöntemleri. Ankara: Seçkin Yayıncılık.

Fwu, B. J. ve Wang, H. H. (2002). The social status of teachers in Taiwan. Compariative Education, 38(2), 211-224. 
Hall, D. ve Langton, B. (2006). Perceptions of the status of teachers Ministry of education. New Zealand: Ministry of Education.

Hesapçıŏlu, M. (1998). Modernizmden postmodemizme eğitim anlayışları ve okulun geleceği. Yeni Türkiye Dergisi 21. Yüzyıl Özel Sayısı I. OcakŞubat Sayısı, 4(19), 813- 820.

Karaaslan, S. (2014). Kuşaklararası farklllıkları örgütler üzerinden anlamak: Bir alan araştırması. (Yayınlanmamış yüksek lisans tezi). Ankara Üniversitesi, Sosyal Bilimler Enstitüsü, Ankara.

Karaman, M., Acer, A., Kılınç, O., Buluş, U. ve Erdoğan, Ö. (2013). Sakarya ilinde görev yapan öğretmenlerin gözüyle öğretmenlik mesleğinin statüsü ve saygınlığı. VI. Ulusal Lisansüstü Eğitim Sempozyumu Bildiriler Kitabı II, s.104-111.

Kaya, B. (2013). Üç kuşak arasındaki değer değişimi. (Yayımlanmamış yüksek lisans tezi). Selçuk Üniversitesi, Sosyal Bilimler Ensititüsü, Konya.

Kayaalp, F. ve Şimşek, U. (2021). Sosyal bilgiler öğretiminde öğrenme amaçlı yazma. S. Polat ve B. Aksoy (Eds). Kuramdan uygulamaya sosyal bilgiler öğretiminde çă̆daş öğrenme ve öğretme yaklaşımları içinde. (s.48-72). Ankara: Pegem Akademi.

Keleş, H. N. (2011). Y kuşağı çalışanlarının motivasyon profillerinin belirlenmesine yönelik bir araştırma. Organizasyon ve Yönetim Bilimleri Dergisi, 3(2), 129-139.

Ker-Dinçer, M. (2000). Işs dünyasında kişisel imajın yeri ve önemi (Yayımlanmamış doktora tezi). Ege Üniversitesi, Sosyal Bilimler Enstitüsü, İzmir.

Kuyucu, M. (2014). Y kuşağı ve facebook: Y kuşağının facebook kullanım alışkanlıkları üzerine bir inceleme. Elektronik Sosyal Bilimler Dergisi, 13(49), 55-83.

Kuyucu M. (2017). Y kuşağı ve teknoloji: Y Kuşağının iletişim teknolojilerini kullanım alışkanlıkları. Gümüşhane Üniversitesi İletişim Fakültesi Elektronik Dergisi, 5(2), 845-872.

Lower, J. (2008). Brace yourself here comes generation Y. Critical Care Nurse, 28(5), 80-84.

Lincoln, Y. S. ve Guba, E. G. (1986). But is it rigorous? Trustworthiness and authenticity in naturalistic evaluation. New directions for evaluation, $30,73-84$. 
Milli Eğitim Bakanlığı (MEB) (2012). Hoş geldin öğretmenim. 2 Ocak 20221 tarihinde http://www.meb.gov.tr/duyurular/duyuruayrinti.asp?ID=8351 adresinden erişildi.

Miles, M. B. ve Huberman, A. M. (2015). Nitel veri analizi (S. Akbaba Altun, A. Ersoy, Çev. Ed.). Ankara: Pegem Akademi.

Morsümbül, Ş. (2014). Kültürel değerlerin üç kuşak arasındaki değişimi üzerine bir inceleme: Ankara örneği. Hacettepe Üniversitesi Türkiyat Araştırmaları Dergisi, 21, 137-160.

Nayır, F. ve Çınkır, Ş. (2017). Değişen zaman, değişen ihtiyaçlar: Türkiye'de kuşaklararası eğitimin karşılaştırılması. Adnan Menderes Üniversitesi Eğitim Fakültesi Ĕ̆itim Bilimleri Dergisi, 8(1), 19-28.

Oblinger, D. ve Oblinger, James L. (2005). Educating the net generation. 02.01.2021 tarihinde https://net.educause.edu/ir/library/pdf/pub7101.pdf internet adresinden erişildi.

Oktay, A. (2001), 21. yüzyılda yeni eğilimler ve eğitim. O. Oğuz, A. Oktay, H. Ayhan (Der.), 21. Yüzyılda Eğitim ve Türk Eğitim Sistemi içinde (s.15-37). İstanbul: Sedar.

Ozankaya, Ö. (2002). Çağdaş toplumlarda öğretmenin yeri ve konumu. İnönü Üniversitesi Egitim Fakültesi Dergisi, 3(3), 63-80.

Ölçüm, D. ve Polat, S. (2016). Evaluation of teacher image on the basis of generations. Journal of Teacher Education and Educators, 5(3), 361-391.

Özoğlu, M. (2010). Türkiye'de öğretmen yetiştirme sisteminin sorunları. Seta Analiz, 17(26), 131-155.

Özoğlu, M., Gür. B. S. ve Altunoğlu, A. (2013). Türkiye'de ve Dünyada öğretmenlik. Eğitim Bir-Sen Yayınları. Araştırma Dizisi, 10.

Özpolat, A. (2002). Sosyolojik açıdan öğretmenlik mesleği ve öğretmenlerin toplumdaki yeri. (Yayımlanmamış doktora tezi). İstanbul Üniversitesi, Sosyal Bilimler Enstitüsü, İstanbul.

Öztürk, B. (2021). Türkiye'de kuşaklar arasındaki siyasi iletişim algılarının farklarl; Kültür ve liderlik perspektifinden bir değerlendirme. Avrasya Uluslararası Araştırmalar Dergisi , 9(26), 331-346.

Pedró, F. ve OECD-CERI (2006). The new millennium learners: Challenging our views on ICT and learning. 02.01.2021tarihinde http://www.oecd.org/dataoecd/1/1/38358359.pdf internet adresinden edinilmiştir.

Prensky, M. (2001). Digital natives, Digital immigrants. On the Horizon, 9(5), $1-6$. 
Sarı, E., ve Harta, G. (2018). Kuşakların tüketim ve satın alma davranışları üzerine bir araştırma. Uluslararası Sosyal Araştırmalar Dergisi, 11(61), 967-980.

Savaş S., ve Karataş, S. (2019). Z kuşağı öğrencisini tanımak. Eğitim Araştırmaları 2019 içinde (s.223-237). Ankara: Eğitim Yöneticileri ve Uzmanları yayınları.

Semerci, Ç., Semerci, N., Eliüşük, A. ve Kartal, S. E. (2012). Öğretmenlik mesleğinin gündemine ilişkin öğretmen görüşleri (Bartın İli Örneği). Bartın Üniversitesi Ĕ̆itim Fakültesi Dergisi, 1(1), 22-40.

Shenton, A. K. (2004). Strategies for ensuring trustworthiness in qualitative research projects. Education for information, 22(2), 63-75.

Taş, H.Y., Demirdöğmez, M. ve Küçükoğlu, M. (2017). Geleceğin mimarları $\mathrm{Z}$ kuşağının iş hayatına muhtemel etkileri. Uluslararası Toplum Araştırmaları Dergisi, 7(13), 1031-1048.

Tavşancıl, E. ve Aslan, A. E. (2001). Sözel, yazll ve diğer materyaller için içerik analizi ve uygulama örnekleri. İstanbul: Epsilon Yayınevi.

TEDMEM (2014). Öğretmen gözüyle öğretmenlik mesleğii. Ankara: Rapor Dizisi: 3.

Tezcan, M. (2017). Kuşaklar çatışması kuşaklararası iliş̧iler eğitimi ve sosyolojisi. Ankara: Anı Yayıncilık.

Tezcek F. Ö (2013). Kapitalizmde emeğin gayri-maddi bileşenleri: TEPAV örneğinde bilgi işçilerinin yükselişi. Eğitim Bilim Toplum, 11(42), 94 164.

Titiz, M. T. (2000). Okulda yeni eğitim. İstanbul: Beyaz.

Türkiye İstatistik Kurumu-TUIKK (2018). Nüfus projeksiyonları 2018-2080 28 Ocak 2021 tarihinde https://tuikweb.tuik.gov.tr/PreHaberBultenleri.do?id=30567 adresinden edinilmiştir.

Türk Eğitim Derneği. (2009). Öğretmen yeterlikleri. Ankara: Adım Okan Matbaacilik.

Ünal, I. L. (2011). Öğretmenliğe ve öğretmen yetiştirmeye ilişkin ekonomi politik bir çözümleme, Songül Aynalı Kilimci (Der.), Türkiye'de öğretmen yetiştirme içinde (s.16). Ankara: Pegem Akademi.

Ünsal, S. ve Bağçeci, B. (2016). Öğretmenlerin mesleki imajlarına ilişkin görüşleri ve mesleki imaja etki eden faktörler. Journal of Human Sciences, 13(3), 3905-3926. 
Ünsal, S., Ağçam, R. ve Korkmaz, F. (2017). Exploring teaching profession from a sociological perspective: Evidence from Turkey. Universal Journal of Educational Research, 5(5), 874-880.

Ünsal, S. (2018). Türkiye'de öğretmenlik mesleğinin statüsüne ilişkin bir pareto analizi . Sakarya University Journal of Education, 8(2) , 111-130.

Yapıcı, M. ve Yapıcı, Ş. (2013). Öğretmen adaylarının pedagojik formasyona ilişkin metaforları. Turkish Studies - International Periodical For The Languages, Literature and History of Turkish or Turkic, 8(8), 1421-1429.

Yelkikalan, N. ve Altın E. (2010). Farklı kuşakların yönetimill. Yönetim Bilimleri Dergisi, 8(2), 13-17.

Yuen, K. ve Hau, K. (2006) Constructivist teaching and teacher-centred teaching: A comparison of students' learning in a university course, Innovations in Education and Teaching International, 43(3), 279-290.

Yıldırım, A. ve Şimşek, H. (2008). Sosyal bilimlerde nitel araştırma yöntemleri. Ankara: Seçkin Yayıncılık.

Yıldız, A. (2013). Türkiye'de öğretmenlik mesleğinin dönüşümü: İdealist öğretmenden sınava hazırlayıcı teknisyen öğretmene. Eleştirel Pedagoji Dergisi, 5(27), 43-50.

Yıldız, A. ve Ünlü, D. (2014). Eleştirel eğitim seçkisi. Baykal N.S, A. Ural, Z. Alica (Der.), Metaforlarla öğretmenliğin dönüşümü: Dün heybetli bir şelaleydik, bugün ise kurumaya yüz tutmuş dere içinde (s.56-67). Ankara: PegamA. Yayıncilık.

Yüksekbilgili, Z. (2013). Türk tipi Y kuşağı. Elektronik Sosyal Bilimler Dergisi, 12(45), 342-353.

\section{Kaynakça Bilgisi / Citation Information}

Tunç Şahin, C., Turan, S. ve Karadeniz, O. (2021). X, Y ve Z kuşaklarının eğitim, öğretmen, öğrenci algıları. OPUS-Uluslararası Toplum Araştırmaları Dergisi, 18(43), 6295-6327. DOI:10.26466/opus.948789. 